\title{
A nova família, de novo - Estruturas e função das famílias contemporâneas
}

\section{The new family, again. Structure and function of contemporary families}

\section{Maria Celina Bodin de Moraes*}

Com licença, eu vou à luta.

(é ilegal ser menor?) **

- E. MACIEL

Marriage is a great institution, but who wants to live in an institution?

$-G$. MARX

\section{Resumo}

Durante muito tempo, as preocupações do legislador acerca da família voltavam-se unicamente para o ato mais solene do direito civil, o casamento e suas consequências jurídicas. A partir da década de 1960, com o reconhecimento da capacidade plena às mulheres casadas e a difusão de métodos anticoncepcionais, diferentes tipos de relações familiares passaram a se articular e a demandar reconhecimento jurídico. Aqui se examinará, em exercício prospectivo, dois movimentos que já se pode entrever: de um lado, a responsabilidade crescente e, por assim dizer, solidarista nas relações parentais; de outro, a expansão da autonomia individual nas relações conjugais.

Palavras-chave: Direito de família. Direitos de crianças e adolescentes. Autonomia existencial. Dignidade da pessoa humana. Família democrática.

* Professora Titular de Direito Civil da Faculdade de Direito da UERJ e professora associada do Departamento de Direito da PUC-Rio. Agradeço a preciosa contribuição de Eduardo Nunes de Souza, mestre e doutorando em Direito Civil pela UERJ, bem como às amigas e professoras Kelly Baião (UFJF), Caitlin Mulholland (PUC-Rio), Renata Vilela (Ibmec) e Ana Carolina Brochado Teixeira (PUC-Minas), com quem tive a oportunidade de trocar ideias sobre o tema. Rio de Janeiro - RJ - Brasil. E-mail: mariacelina.bodin@terra.com.br

** Título do livro autobiográfico de Eliane Maciel, lançado pela Editora Rocco em 1970 e levado ao cinema em 1986, sob a direção de L. Farias. 


\section{Abstract}

For a long time, the concerns of the law makes about the family institution were exclusively focused on the "most solemn act" of private law, as marriage and its legal implications. In Brazil, since the 1960s, as result of the grant of legal civil capacity to married women and the spread of contraceptive pill, different kinds of family arrangements emerged, demanding legal recognition. The present work examines, in an exercise in futurology, two guidelines that begin to take shape to regulate the family of this century: the issue of autonomy in conjugal relationships and the full responsibility towards children's protection.

Keywords: Family law. Children's fundamental rights. Children's protection. Human dignity. Democratic family.

\section{Introdução}

A consagração da dignidade da pessoa humana como fundamento da República, no art. $1^{\circ}$, III, da Constituição Federal de 1988 - dispositivo inicialmente recebido com certo ceticismo (BARROSO, 1990) -, mostrouse uma conquista decisiva, que revolucionou a ordem jurídica privada. A opção do constituinte ao elevar tal princípio ao topo do ordenamento modificou radicalmente a estrutura até então vigente no direito brasileiro. Sem dúvida, os efeitos dessa alteração na interpretação/aplicação dos institutos jurídicos, em especial dos de direito civil, têm sido notáveis e ainda não se encontram inteiramente concluídos.

Do ponto de vista do direito de família, a proposta de constitucionalização dá sinais de ampla e acelerada consolidação, tendo tomado por base a cláusula geral de tutela da pessoa humana, bem como dois marcantes dispositivos constitucionais: o art. $226, \S 5^{\circ} \mathrm{da}$ Constituição, que estabeleceu a igualdade dos cônjuges no casamento, e o art. 227, que atribuiu aos filhos a posição de centralidade no grupo familiar, garantindo "absoluta prioridade" às crianças e aos adolescentes. O patriarcalismo, como se sabe, fundava-se na tripla desigualdade de homens em relação a mulheres, de pais em relação a filhos e de heterossexuais em relação a homossexuais (SINGLY, 2000). Para fazer 
frente à estrutura patriarcal então vigente, o constituinte pôs fim, nos aludidos dispositivos, a duas dessas desigualdades.

Quanto à terceira desigualdade, ao se ampliarem as formas de organização da família (art. 226, $\S \S 3^{\circ}$ e $4^{\circ}$ ), abriu-se o texto constitucional à possibilidade de proteção de novas estruturas familiares (BODIN DE MORAES, 2000). Foi essa a tese aceita pelo Supremo Tribunal Federal (STF) para garantir o direito à união homoafetiva no país. Em maio de 2011, ao julgar a Ação Direta de Inconstitucionalidade (ADIn) 4.277 e a Arguição de Descumprimento de Preceito Fundamental (ADPF) 132, a Corte reconheceu, por unanimidade, a constitucionalidade da união entre pessoas do mesmo sexo ${ }^{1}$. Para alguns, ainda haveria distinção entre a união estável e o casamento de pessoas do mesmo sexo, uma vez que a decisão do Supremo não fizera qualquer menção ao casamento. No entanto, na sessão de 14 de maio de 2013, o Conselho Nacional de Justiça (CNJ) aprovou, por substancial maioria (14 a 1), resolução para obrigar os cartórios do país a habilitar e celebrar o casamento civil entre pessoas do mesmo sexo e a converter a união estável homoafetiva em casamento ${ }^{2}$.

O modelo adotado pelo constituinte pressupõe a existência de uma pluralidade de estruturas familiares (ditas redes ou enxames), nenhuma delas podendo apresentar legitimidade superior, pois todas manifestam igual potencial de desenvolver as funções intrínsecas à família, tais como o cuidado, o respeito e a educação das crianças, a solidariedade e a mútua assistência entre seus membros (ROUDINESCO, 2003). Embora se reconheça uma resistência às mudanças sociais e jurídicas por

\footnotetext{
O relator das ações, Min. Ayres Britto, votou a fim de excluir qualquer significado do art. 1.723 do Código Civil que fosse impeditivo ao reconhecimento da união entre pessoas do mesmo sexo. $\mathrm{O}$ relator sustentou que o art. $3^{\circ}$, IV, da Constituição veda qualquer discriminação em virtude de sexo, raça, cor e que, nesse sentido, ninguém pode ser diminuído ou discriminado em função de sua preferência sexual: "O sexo das pessoas, salvo disposição contrária, não se presta para desigualação jurídica", afirmou, para concluir que qualquer depreciação da união estável homoafetiva colide frontalmente com a Constituição.

2 Resolução $n^{\circ} 175 / 2013$, que proíbe as autoridades competentes a se recusarem a habilitar, celebrar casamento civil ou de converter união estável em casamento entre pessoas de mesmo sexo.
} 
parte dos defensores da família tradicional, a pluralidade de entidades familiares mostra seu dinamismo como organismos vivos e ativos que são, culturalmente determinados e em constante mudança.

Não cabe analisar aqui o caminho percorrido; cumpre, a partir dessa conhecida história, tentar empreender uma espécie de exercício de futurologia ${ }^{3}$ acerca dos rumos do direito de família de agora em diante. Esse nosso tempo, de vertiginosas mudanças e de tão poucas certezas, demanda-nos lançar os olhos em prospectiva e buscar enxergar novos instrumentos para enfrentar problemas éticos, políticos e sociais que já existem, mas com os quais ainda não sabemos como lidar (BAUMAN, $2012)^{4}$. Os movimentos intrafamiliares que podem ser identificados são, de um lado, a forte expansão da autonomia individual nas relações conjugais; de outro, a responsabilização crescente, solidarista, ${ }^{5}$ nas relações parentais.

\section{0 valor e a função da família democrática}

Diagnosticada, ao longo de boa parte do século XX, como uma instituição em crise, decadente e destinada a desaparecer (COOPER, 1986), a estrutura familiar transformou-se, passando paulatinamente a corresponder a muitas das aspirações individuais presentes no mundo ocidental (EEKELAAR, 2001). Crise houve, mas não investiu contra a família em si: seu alvo foi o modelo familiar "monárquico" - absoluto, perpétuo e totalizante. Em virtude da cada vez maior fragmentação social, a ideia de ambiente familiar experimenta, na contemporaneidade,

3 De acordo com o Dicionário Houaiss, significa, dentre outras acepções, o estudo que trata das possibilidades futuras, levando em conta tendências manifestadas no presente.

4 Segundo Bauman: "Recentemente, eu comecei a chamar a presente situação de 'situação de interregno'. O interregno é um conceito bem antigo, da época de Tito Lívio, que escreveu a história de Roma em $A b$ Urbe Condita ["desde a fundação da cidade"]. Um interregno significa, simplesmente, que a antiga maneira de agir não funciona mais, e novos modos de agir ainda não foram inventados".

5 Propõe-se o termo "solidarista" para se evitar eventual confusão com a responsabilidade solidária prevista pelo clássico direito das obrigações; trata-se, evidentemente, de uma responsabilidade pautada pelo princípio da solidariedade familiar. 
um momento de esplendor, "tendo se tornado um anseio comum de vida, com o desejo generalizado de fazer parte de formas agregadas de relacionamento baseadas no afeto recíproco" (ROUDINESCO, 2003) ${ }^{6}$.

Compreende-se, assim, que o exercício do poder no âmbito da família mudou e não pode mais ser visto em função de uma hierarquia entre pais e filhos; muito menos entre os cônjuges ${ }^{7}$. Nos países ocidentais, o poder marital desapareceu, tendo havido, em seguida e em consequência, a supressão da figura do "chefe de família"8. Além disso, outros diversos fenômenos sociodemográficos contribuíram para a alteração radical da vida familiar. Quanto ao casamento, por exemplo, numerosos foram os casais que decidiram passar a coabitar, independentemente de vínculo formal; outros decidiram morar em casas separadas, permanecendo casados; tantos outros se divorciaram (e mais de uma vez); inúmeras foram as crianças nascidas de pais não casados, de pais desconhecidos, de pais ignorados. Concomitantemente, mais mulheres começaram a trabalhar fora e a compartilhar os encargos econômicos da família; para tanto, muitas adiaram o início da vida conjugal em prol da construção de uma trajetória profissional, passando a ter filhos cada vez mais tarde, quando já dotadas de alguma independência financeira.

Esse processo foi acompanhado de perto pela legislação e pela jurisprudência brasileiras, as quais inegavelmente cumpriram, nas últimas décadas, importante papel promocional na construção de novas entidades familiares, que são plurais justamente porque deixadas à escolha de seus membros. Se fosse possível reuni-las em um gênero,

6 Diz ainda Roudinesco (2003, p. 198): "A família é atualmente reivindicada como o único valor seguro ao qual ninguém quer renunciar. Ela é amada, sonhada e desejada por homens, mulheres e crianças de todas as idades, de todas as orientações sexuais e de todas as condições."

7 Um dos nossos maiores problemas sociais está, como é notório, na concreta desigualdade da mulher no âmbito conjugal. Essa desigualdade, não obstante o expresso teor da norma constitucional e de tantas outras regras na legislação ordinária, tem hoje, pelo menos, ampla visibilidade, e um de seus mais terríveis aspectos está na corriqueira violência doméstica considerada um problema de saúde pública. A propósito da sua disseminação, é comum se ouvir dizer que o lugar mais perigoso para uma mulher é dentro da própria casa.

8 Segundo Pittman (1993, p. 6): "Family life in Western society since the Old Testament has been a struggle to maintain patriarchy, male domination, and double standards in the face of a natural drift towards monogamous bonding." 
esse novo modelo poderia ser denominado "democrático" (GIDDENS, 1993) - correspondente, em termos históricos, a uma significativa novidade: a inserção, no ambiente familiar, de direitos fundamentais como a igualdade e a liberdade. De fato, cinquenta anos depois do movimento cultural de jovens que consideravam a família a principal fonte de repressão, rigidez e conformismo social, ela tem sido vista como um espaço privilegiado de solidariedade e realização pessoal, o que se deve ao fato de não poderem mais ser ignorados os direitos da personalidade de seus membros (SILVA PEREIRA; MELO, 2000).

Em outras palavras, em contraposição ao modelo familiar tradicional e findas as desigualdades mencionadas, tornou-se possível propor uma configuração democrática de família, na qual não há direitos sem responsabilidades, nem autoridade sem democracia. A democratização no contexto da família implica alguns pressupostos específicos, tais como a igualdade, o respeito mútuo, a autonomia, a tomada de decisões através da comunicação, o resguardo da violência e a integração social. Nas famílias democráticas, distribui-se o poder de decisão: todos devem ter iguais e adequadas oportunidades de falar, e todos devem ser capazes e estar interessados em ouvir (GIDDENS, 1993). O adjetivo "democrático" diz respeito à rejeição de qualquer discriminação e preconceito, à liberdade de decidir o curso da própria vida e ao direito de protagonizar igual papel ao forjar um destino comum ${ }^{9}$.

No modelo tradicional, a relação conjugal indissolúvel era o que fundava a família, portanto, era considerada o seu núcleo central, o eixo de estabilidade em relação ao qual os membros orbitavam. A liberdade estava ausente; basta lembrar que os homens casados não podiam, nem se quisessem, reconhecer a filiação fora do casamento regra absoluta que foi sendo aos poucos relativizada, até sua completa eliminação pelo constituinte de 1988. A relação parental dita "ilegítima" - isto é, não legitimada pelo casamento - contrariava a moralidade

9 Sobre o tema, v. Bodin de Moraes (2010, p. 207-234). 
jurídica da época e, consequentemente, devia ser repudiada a todo custo, para não prejudicar a "paz doméstica"10. Embora ainda se consiga encontrar resquício desse tipo de proteção no Código de 2002 - por exemplo, o art. 1.611 estabelece que "o filho havido fora do casamento, reconhecido por um dos cônjuges, não poderá residir no lar conjugal sem o consentimento do outro" -, o valor primordial que adquiriram as relações parentais no ordenamento atual se mostra incontestável. A propósito de tantas profundas mudanças, a atenta doutrina já ponderava acerca do fundamento da família no mundo contemporâneo:

Qual a função atual da família? Se é certo que ela é a base da sociedade, qual o papel que ela cumpre desempenhar, já que não tem mais funções precipuamente religiosa, econômica ou política como outrora? Qual a base que se deve dar à comunidade familiar para que alcance a tão almejada estabilidade, tornando-a duradoura? Devemos reunir todas essas funções ou simplesmente considerar o seu verdadeiro e talvez único fundamento: a comunhão de afetos? (BARBOZA, 1994).

Famílias democratizadas nada mais são do que famílias em que a dignidade de cada membro é respeitada e tutelada. Para a concretização desse processo, o que mais cumpre ressaltar é a sua pluralidade: o fenômeno familiar não é mais unitário, tendo deixado o casamento de servir de referência única do grupo familiar. Como se viu, depois de 1988, foram expressamente admitidas entidades diversas e a Constituição reconheceu, em rol exemplificativo, estruturas diferenciadas de relacionamentos familiares, de modo que outras entidades se tornaram possíveis e até mesmo desejáveis: além das uniões estáveis e das famílias monoparentais, famílias recombinadas, famílias homoafetivas

10 Não custa referir que em países supostamente mais desenvolvidos culturalmente, como a Itália, o filho havido "fora do casamento" continuou a ser considerado "ilegítimo" por mais de trinta anos em relação ao Brasil, isto é, até dezembro de 2012, quando a Lei n. 219, intitulada "disposições em matéria de reconhecimento dos filhos naturais", finalmente adotou o princípio da igualdade entre os filhos. 
e até mesmo famílias concubinárias e simultâneas ${ }^{11}$ usufruem, hoje, de proteção legal| ${ }^{12}$.

Às relações familiares - tanto as conjugais quanto as paternofiliais - cabe aludir justamente para mostrar a sua transformação. Nesse ponto, deve-se sublinhar que, na disciplina jurídica das famílias, há componentes de ordem pública tão relevantes que o legislador frequentemente lhes atribui a característica de normas imperativas ${ }^{13}$. No entanto, como se verá, a proteção dos direitos fundamentais no interior da família traz consequências bem diferentes, conforme se trate de relações conjugais ou de relações parentais. Nas primeiras, ela aponta no sentido da ampliação da autonomia do casal, com a consequente diminuição de normas cogentes; nas segundas, ao contrário, o aumento da responsabilidade faz com que a liberdade no exercício da parentalidade deva ser limitada.

\section{A relação entre saúde psíquica individual, ambiente familiar e democracia}

Parte-se aqui da necessidade humana de um crescimento saudável no âmbito familiar, em busca de um tratamento jurídico promocional e mais adequado para as entidades familiares. A respeito, importa ressaltar a intrínseca relação entre autonomia e dignidade e o papel decisivo que o ambiente familiar desempenha no progresso individual e, em consequência disso, na evolução social. Efetivamente, existe uma relação nem sempre lembrada entre o já aludido modelo

11 No STJ, em 2012, a Quarta Turma, sob a relatoria do Ministro Luís Paulo Salomão, em decisão unânime, entendeu não ser possível a existência paralela de duas uniões estáveis. No entanto, frequentemente, a Terceira Turma procede à tutela simultânea: v., infra, o n. 5 (através da ampliação do conceito de bem de família). Sobre a discussão acerca do princípio da monogamia, na doutrina, remete-se ao profundo estudo de Marcos ALVES DA SILVA. Da monogamia: a sua superação como princípio estruturante do direito de família. Curitiba: Juruá, 2013. No Código Civil, v. o art. 1.727 para a definição de concubinato.

12 Formas alternativas, como as chamadas "uniões poliafetivas", não foram consideradas.

13 Nas palavras de Pierre Bourdieu: "Famille. Cette réalité dite privée d'origine publique". 
democrático ou solidário de família e o projeto de construção de uma sociedade democrática e solidária.

O primeiro requisito para o livre e pleno desenvolvimento da personalidade humana é o fato de a pessoa ser dotada de discernimento e vontade própria, ou, em uma palavra, de autonomia. ${ }^{14} \mathrm{O}$ agir livre e autônomo tem sido associado ao adequado desenvolvimento humano pelas mais diversas áreas do conhecimento, sendo uma vinculação amplamente aceita e propalada por autores das mais variadas correntes de pensamento. Pouco se comenta, porém, que é no âmbito familiar que o indivíduo começa a desenvolver sua personalidade de modo saudável e a construir a autonomia de que precisará futuramente, no meio social, para a condução de uma sociedade democrática - que se revelará igualmente fundamental para a sua existência digna.

Em nosso tempo, é frequente a afirmação de que o sistema institucional fundado em valores "baseados na família, na religião, nos ideais políticos e usado na elaboração do 'sentido da vida' dos indivíduos sofreu brutal transformação"; e isso tem levado a "previsões de tal modo catastróficas" (COSTA, 2012) sobre todos os aspectos do futuro da humanidade. Alguns cientistas chegaram a dizer que temos chances razoáveis de não alcançar o final do século ${ }^{15}$.

Há algo a fazer? Para o psiquiatra e pediatra Donald Winnicott - cuja experiência profissional, ao contrário de Freud, não se deu com indivíduos neuróticos e infelizes, mas com bebês saudáveis e doentes - a noção de "indivíduo saudável" existe e decorre, essencialmente, da possibilidade de se experimentar o sentimento de "uma continuidade do ser", ou melhor, "a experiência de que a vida faz sentido, e de que vale

\footnotetext{
14 A conexão entre o valor da liberdade e a dignidade humana já foi explicitada, pelo prisma kantiano, em Bodin de Moraes (2010).

15 V. LESLIE, John. The End of the World: The Ethics and Science of Human Extinction. London: Routledge, 1996; BOSTROM, Nick. "Existential Risks: Analyzing Human Extinction Scenarios and Related Hazards". Journal of Evolution and Technology. Vol. 9 (2002); REES, Martin. Our Final Hour. A Scientist's Warning: How Terror, Error, and Environmental Disaster Threaten Humankind's Future In This Century - On Earth and Beyond. New York: Basic Books, 2004.
} 
a pena vivê-la" (NÁPOLI, 2011). É essa "âncora subjetiva” o elemento fundamental que todo ser humano deve possuir para conseguir lidar, de modo não problemático, com as venturas e desventuras de sua existência. A teoria winnicottiana diferencia o conjunto das pessoas em dois tipos: aquelas que não se desapontaram na primeira infância (e, na mesma medida, "são candidatas a viver alegremente e a aproveitar a vida") e aquelas que sofreram experiências traumáticas, provenientes de decepções com o ambiente, carregando consigo as lembranças do estado em que se encontravam no momento do desastre - são estas, segundo o autor, as "candidatas a levar vidas tempestuosas e talvez candidatas à doença"16 (WINNICOTT, 1999, p. 15).

Um dos principais suportes do equilíbrio mental é justamente o sentimento de que a vida vale a pena: "mais do que nossa vida individual, é o que deixamos no mundo, como produto do nosso trabalho e expressão, que tem valor e acrescenta algo às futuras gerações" (COSTA, 2012). Isso exige a "hercúlea tarefa, para a qual, porém, temos aptidão e capacidade, de criar condições favoráveis à emergência de nossa espontaneidade para agir e para confiar, de antemão, na boa vontade do outro" (Ibidem). Indivíduos que se desenvolvem sem essa autonomia são incapazes de adquirir maturidade para realizar ações construtivas, em benefício de todos, com base nos ideais de justiça, liberdade e amor ao outro. O resultado são sociedades, de um lado, violentas, de outro, passivas e sujeitas a toda sorte de paternalismo. A democracia se encontra, assim, no início e no final de uma linha contínua de desenvolvimento do indivíduo e de sua autonomia.

A criação de um ambiente saudável, democrático e hábil à construção da autonomia individual é que deve pautar a responsabilidade dos pais na criação dos filhos menores. É nesse sentido que se afirma

16 Evidentemente, o autor aponta a existência de um grupo intermediário: “(...) são aqueles que trazem consigo a experiência de ansiedades impensáveis ou arcaicas, e que estão mais ou menos bem defendidos (...) caso as pessoas dessa categoria consigam agarrar-se, ainda que tardiamente, à tendência em direção ao desenvolvimento, elas poderão ser bem sucedidas e poderemos incluí-las entre os saudáveis. Saudáveis por bem ou por mal” (p. 15). 
que a família deve ser algo privilegiado para o fortalecimento da personalidade de seus membros, em particular, das crianças. A tarefa é, evidentemente, trabalhosa: não podem os pais simplesmente estalar os dedos ou piscar os olhos para que seus filhos absorvam seu código de ética e suas regras de comportamento; é preciso ensinar, instruir, dar exemplos, usar recompensas e castigos, e assim por diante. Diz Winnicott (1999, p. 118): "Conhecemos algumas razões que fazem essa longa e exigente tarefa - o trabalho dos pais de cuidar dos filhos - valer a pena, e, de fato, acreditamos que esse trabalho provê a única base real para a sociedade, sendo o único fator para a tendência democrática do sistema social de um país".

Embora de modo diverso, na mesma direção se manifesta o psiquiatra James Gilligan, presidente do Center for The Study of Violence, vinculado à Harvard Medical School, onde, durante mais de quarenta anos, conviveu com "os mais violentos membros de nossa sociedade". Como sabemos, de muito pouco tem adiantado reprimir a violência. Não seria o caso, então, de tentar tratar suas causas, e não, como temos feito desde sempre, de punir suas consequências ${ }^{17}$ Gilligan verificou que famílias violentas geram indivíduos violentos, os quais alimentam a sociedade da violência e são por ela alimentados. Segundo pôde perceber claramente, havia entre esses indivíduos um importante denominador comum: "ou haviam sofrido severíssimos abusos durante a infância (a ponto de alguns terem sobrevivido a tentativas de assassinato nas mãos de seus pais) ou haviam, também na infância, perdido entes queridos em episódios igualmente violentos" (GILLIGAN, 2011) ${ }^{18}$. A violência doméstica contra crianças e adolescentes está presente em toda ação ou omissão praticadas por pais, parentes

17 Afirma Gilligan (2001, p. 7): "For the past four millennia, since the time of the first law-givers Hammurabi and Moses, Drakon and Solon, Plato and Aristotle, Cicero and Justinian - humanity has been engaged in a great social experiment, testing the hypothesis that we could prevent violence, or at least diminish its scale and intensity, by labeling it "evil" and "criminal"; ordering people not to engage in it; and then, when they commit acts of violence anyway retaliating with more violence of our own, which we call "punishment" and "justice".

18 James GILLIGAN, depoimento no documentário Zeitgeist: Moving Forward, Part. I: Human Nature, dirigido por Peter Joseph, divulgado em 26.01.2011, disponível em: <http://www.youtube. com/watch? v=4Z9WVZddH9w>. Acesso em 3 mai. 2013. 
ou responsáveis contra crianças e adolescentes, o que implica, de um lado, a transgressão do poder-dever de proteção do adulto e, de outro, a reificação da infância, isto é, a negação do direito que crianças e adolescentes têm de ser tratados como sujeitos, pessoas em condição peculiar de desenvolvimento (GUERRA,1998, p. 32-33).

Para Gilligan, as prisões são microcosmos das sociedades em que estão inseridas e, ao examiná-las, aprendemos sobre essas sociedades como um todo. Bem se sabe que o desgosto, o nojo e a vergonha pertencem a todos os seres humanos, assim como a raiva e a agressividade, mas o mesmo não ocorre em relação à sua exteriorização. A violência não é compulsória nem automática ${ }^{19}$. Gilligan sugere tratar a violência como um problema de saúde pública. Ele defende iniciar uma mudança social e econômica radical para atacar as causas da violência, e propõe o abandono do restrito paradigma da punição e da sociedade de vingança ${ }^{20}$. De fato, vivemos o século $X X$ completamente mergulhados na violência. "Se tentarmos entender a violência dos indivíduos, isso pode vir a impedir a violência coletiva que ameaça nosso futuro muito mais do que todos os crimes individuais juntos" ${ }^{21}$.

A propósito, é fato que muito poucos países são mais violentos do que o Brasil ${ }^{22}$, tanto no âmbito familiar ${ }^{23}$ como no social. ${ }^{24}$ Lembremo-

19 Gabor MATÉ, em depoimento no documentário citado.

20 GILLIGAN, James. em depoimento no documentário citado

21 Idem, ibidem.

22 Em 2010, o Brasil registrou cerca de 36 mil mortes por arma de fogo (recorde mundial). No mesmo período, os Estados Unidos, com uma população de cerca de 100 milhões a mais de pessoas e com uma política de livre aquisição de armas, registraram menos de 10 mil mortes. Em termos relativos, em 2010, a taxa de óbitos por arma de fogo nos EUA foi de 3,2 por 100 mil habitantes; no Brasil, de 19,3 mortos por 100 mil habitantes. Dados disponíveis em: <http:// www.bbc.co.uk/portuguese/noticias/2012/12/121218_armas_brasil_eua_violencia_mm.shtml>. Acesso em 20 dez. 2012.

23 Waiselfisz (2012): "Nos 30 anos decorridos entre 1980 e 2010 foram assassinadas no país mais de 92 mil mulheres, 43,7 mil só na última década. O número de mortes anuais, nesse período, passou de 1.353 para 4.465 , o que representa um aumento de $230 \%$, mais do que triplicando o quantitativo de vítimas de assassinato no país". Disponível em: <http://www.mapadaviolencia. org.br/pdf2012/MapaViolencia2012_atual_mulheres.pdfs. Acesso em 20 mai. 2013. Os números continuam a crescer, mesmo depois da promulgação da Lei Maria da Penha em 2007.

24 De acordo com o sociólogo Guaracy Mingardi, "no Brasil, a violência interpessoal, que engloba briga de bar, de vizinho, marido e mulher, responde por mais da metade das mortes". Disponível em: <http://www.bbc.co.uk/portuguese/noticias/2012/12/121218_armas_brasil_eua_violencia_ mm. shtml>. Acesso em 20 dez. 2012. 
nos ainda de que, hoje, tudo o que serve para pacificar nossa sociedade enfrenta um formidável obstáculo. Como bem sabe o marketing, na sociedade do consumo, para aumentar a lucratividade, basta criar um problema - assim, poder-se-á vender a solução. No caso da violência, o lucro é imenso: é o lucro da guerra.

\section{0 problema da responsabilidade parental}

Em um fórum de perguntas e respostas na internet, uma moça conta sua história: "Descobri que estava grávida no primeiro mês de gravidez. Conheci o possível pai biológico da minha filha numa 'ficada'. Passamos apenas uma semana nos vendo e antes de saber que estava grávida, já havia cortado relações com ele. Desde o começo da gravidez, estive decidida a criar minha filha sozinha e sempre deixei isso bem claro para ele. Pedi para ele se manter distante porque, afinal de contas, não o conhecia o suficiente para deixá-lo participar dessa hora tão minha. (...). Minha filha nasceu e um mês depois ele veio ao meu prédio me comunicar que entraria na Justiça para poder registrar a filha e, daí, poder visitá-la etc.". A moça, então, indagava: "O que eu posso fazer para evitar o contato entre ele e minha filha? Não pretendo deixar a minha menina, hoje com um mês, nas mãos de um semidesconhecido. Posso negar a paternidade?".

Nessa mesma tendência, proliferam às dezenas os registros de falsos abusos que chegam à Justiça anualmente. Nas varas de família da capital do Rio de Janeiro, cerca de $80 \%$ das denúncias são falsas: "na maioria dos casos, a mãe está recém-separada e denuncia o pai para restringir as visitas", explica a psicóloga do Tribunal de Justiça do Rio de Janeiro (TJRJ) ${ }^{25}$. Especialistas relatam que a invenção é discreta e "o adulto denunciante vai convencendo a criança aos poucos

25 Entrevista realizada em 27.05.2012. Disponível em: <http://extra.globo.com/noticias/rio/ nas-varas-de-familia-da-capital-falsas-denuncias-de-abuso-sexual-podem-chegar-80-dosregistros-5035713.html>. Acesso em 27 abr. 2013. 
de que a agressão realmente aconteceu". Com técnicas adequadas, por intermédio de diversas entrevistas, é possível detectar a mentira; todavia, aquela "verdade inventada" pode provocar na vítima os mesmos danos psicológicos de um abuso sexual real.

Quando um casal decide ter filhos, confia que a parentalidade seja algo inato e que sua experiência como filho será suficiente para o exercício do novo papel. No entanto, apesar de ser um processo tão antigo quanto a humanidade, a parentalidade é um desafio repleto de problemas, dificuldades, medos e dúvidas. "Em especial, o nascimento do primeiro filho configura-se como um evento determinante na vida adulta e, consequentemente, em seu processo de desenvolvimento; as implicações daí advindas impõem mudanças nos mais diversos níveis, pessoal e social, e demandam respostas imediatas, com frequência completamente desconhecidas pela grande maioria dos pais" (BOTTON, 2011).

Cada vez se tem mais consciência de que os cuidados prestados ao bebê nos primeiros anos se tornarão cruciais para a saúde mental da criança, ao mesmo tempo em que marcas de abusos e descuidos permanecerão ao longo da idade adulta e provavelmente alcançarão o indivíduo até o fim de sua vida (WINNICOTT, 1999). Já está mais do que comprovada cientificamente a importância, para o futuro adulto, dos cuidados e atenção recebidos, ou não, desde os primeiros momentos da gravidez (NEUFELD; MATÉ, 2005) ${ }^{26}$. Na síntese de Alain de Botton, parece impossível nos sentirmos importantes para nós mesmos, "suficientemente dignos de conduzir nossa figura absurda pelos labirintos da vida, a não ser que em algum momento nós tenhamos sido privilegiados o suficiente para desenvolver um sentimento de que

26 Ressalte-se que, no Brasil, cerca de 700 mil crianças nascem, a cada ano, de "pai desconhecido". Sobre esse dado e outras estimativas impressionantes, v. o livro da socióloga Ana Liési Thurler, Em nome da mãe - o não reconhecimento paterno no Brasil. Diz a socióloga: "Esses homens nem suspeitam que são o maior objeto do desejo de seu filho ou sua filha. Não é só o dinheiro ou o sobrenome. O que falta a essas crianças, jovens e adultos sem pai é algo chamado reconhecimento. Não o legal, mas o amoroso. É o acolhimento". 
outra pessoa se importava de forma ilimitada e desmedida conosco" (BOTTON, 2011).

Uma das mais importantes consequências da mudança paradigmática ocorrida no direito de família foi a criação de diversos instrumentos para a proteção da criança em relação aos próprios pais, à própria família. No passado, essa proteção mostrou-se talvez menos necessária porque a educação estava, normalmente, diluída entre avós, primos, tios - famílias grandes e, portanto, numa rede de apoio diversificada. Famílias desse porte e com tais características não existem mais ${ }^{27}$. Nesse cenário, e como os filhos menores não estão em condições de se protegerem por si sós, o Estado, especificamente o legislador e o juiz, tomou para si o encargo de tutelá-los em face de todos, inclusive dos próprios pais. Passou-se, assim, do modelo tradicional, dito proprietário ou não intervencionista, segundo o qual as crianças só têm os direitos que os pais permitem - não sendo admissível qualquer oposição entre pais e filhos menores $-^{28}$, à conscientização de que a liberdade individual, se pode pôr em risco a vida de outro, não pode ser exercida sem restrições e controle.

Ao adotar o modelo intervencionista, a lei cada vez mais garante aos filhos proteção, direitos e liberdades, atribuindo aos pais deveres e responsabilidade ${ }^{29}$. O termo "responsabilidade" é o que melhor define atualmente a relação de parentalidade. Trata-se de uma relação assimétrica entre pessoas que estão em posições diferenciadas, sendo uma delas dotada de efetiva vulnerabilidade (ainda que temporária). Essa assimetria, enquanto os filhos são menores, tende a ser perene, sendo custoso e excepcional o seu término. De fato, a perda ou a

27 Basta pensar que o parentesco colateral, que no CC2002 alcança apenas quatro graus, na época da promulgação do CC1916, atingia doze graus.

28 Assim, dentre outros, pensa Moro (2001), segundo o qual não é possível haver um conflito intrafamiliar porque o direito do genitor e o direito do filho menor configuram, ambos, situações jurídicas subjetivas ativas.

29 A crítica normalmente feita ao modelo intervencionista é a de que se o princípio do melhor interesse da criança a nada cede, por via oblíqua, em ultima ratio, está-se sustentando que é o Estado Juiz o único a deter seu conteúdo. Nesse sentido, considerando indevida qualquer "intromissão" do Estado, v. Goldstein (1998). 
suspensão do poder familiar somente ocorre em casos de elevado risco ou de abuso.

À família como instituição corresponde a atual família democratizada, criada e protegida pela Constituição de 1988, cujos protagonistas são os filhos. Desse microcosmo começam a ser partes integrantes aspectos que antes ficavam da porta para fora: direito ao respeito ${ }^{30}$, garantia de liberdade de crença ${ }^{31}$, proteção em face da síndrome da alienação parental ${ }^{32}$, garantia do estado de filiação ${ }^{33}$, direito de conhecer as origens genéticas ${ }^{34}$, averiguação oficiosa da paternidade ${ }^{35}$, presunção legal de paternidade em caso de recusa ao exame de DNA $^{36}$ e responsabilização civil por abandono moral ${ }^{37}$ foram alguns dos instrumentos postos, nos últimos anos, a serviço da proteção dos filhos em face de seus próprios genitores. Outros mais recentes

30 Estatuto da Criança e do Adolescente (ECA): "Art. 17. O direito ao respeito consiste na inviolabilidade da integridade física, psíquica e moral da criança e do adolescente, abrangendo a preservação da imagem, da identidade, da autonomia, dos valores, ideias e crenças, dos espaços e objetos pessoais".

31 ECA, art. 16, III.

32 Lei n. 12.318/2010, dita Lei SAP.

33 Na doutrina, por todos, Lobo Neto (2004, pp. 47-56).

34 Ibidem.

35 Lei n. 8560/1992, a qual, no art. $4^{\circ}$, já previa que "o filho maior não pode ser reconhecido sem o seu consentimento", disposição hoje constante do art. 1.614 do Código Civil, acrescido do seguinte trecho: "e o menor pode impugnar o reconhecimento nos quatro anos que se seguirem à maioridade ou à emancipação".

36 Lei n. 12.004/2009. Para uma solução diversa, impondo a realização do exame, v., de recente, TJRJ, 6 ${ }^{a}$ C.C., Ap. cível 2009.001.31427. Rel. Des. Nagib Slaibi, julg. 07.04.2010.

37 Nesse ponto, ressalte-se a relevante inflexão no pensamento da Terceira Turma do STJ, através do voto condutor da Min. Nancy Andrighi: "(...) Aqui não se fala ou se discute o amar e, sim, a imposição biológica e legal de cuidar, que é dever jurídico, corolário da liberdade das pessoas de gerarem ou adotarem filhos. $\mathrm{O}$ amor diz respeito à motivação, questão que refoge os lindes legais, situando-se, pela sua subjetividade e impossibilidade de precisa materialização, no universo meta-jurídico da filosofia, da psicologia ou da religião. O cuidado, distintamente, é tisnado por elementos objetivos, distinguindo-se do amar pela possibilidade de verificação e comprovação de seu cumprimento, que exsurge da avaliação de ações concretas: presença; contatos, mesmo que não presenciais; ações voluntárias em favor da prole; comparações entre o tratamento dado aos demais filhos - quando existirem -, entre outras fórmulas possíveis que serão trazidas à apreciação do julgador, pelas partes". (STJ, $3^{a}$ T., REsp 1.159.242, Rel. Min. Nancy Andrighi, julg. em 24.04.2012). No mesmo sentido, posiciona-se ampla doutrina, remetendo-se aqui a Bodin de Moraes (2005, pp. 39-66). 
foram a guarda compartilhada ${ }^{38}$, o direito à visita dos avós ${ }^{39}$, os alimentos gravídicos ${ }^{40}$ e o reconhecimento de parentesco socioafetivo ${ }^{41}$. De lege ferenda, tramita no Congresso Nacional o projeto de lei que proíbe os castigos físicos ${ }^{42}$.

O marco inicial desse tratamento privilegiado foi a Convenção Internacional sobre os direitos das crianças (Resolução n. 44/25 da ONU), de 1989, o documento internacional que mais interesse atraiu, tendo sido assinado e ratificado pelo mundo inteiro ${ }^{43}$. O princípio germinal da Convenção, que dela se espraiou para substituir a até então invisibilidade social da infância, é o princípio do "melhor interesse da

38 Lei n. 11.698/2008, que deu nova redação aos arts. 1.583 e 1.584 do Código Civil.

39 Lei n. 12.398/2011, que acrescenta parágrafo único ao art. 1.589 do Código Civil.

40 Lei n. 11.804/2008, cujo art. $6^{\circ}$ dispõe: "Convencido da existência de indícios da paternidade, o juiz fixará alimentos gravídicos que perdurarão até o nascimento da criança, sopesando as necessidades da parte autora e as possibilidades da parte ré."

41 Na doutrina, dentre outros, Chinelato (2003, p. 63 ss.) e Lobo Neto (2006, pp. 795-810). Na jurisprudência, STJ, 29.02.2012: "Exame de DNA negativo não basta para anular registro de nascimento. Para obter êxito em ação negatória de paternidade é necessário comprovar a inexistência de vínculo genético e, além disso, de vínculo social e afetivo." Disponível em: <http:// www.stj.gov.br/portal_stj/publicacao/engine.wsp?tmp.area=398 \&tmp.texto=104858>. Acesso em 30 fev. 2012.

42 Projeto de Lei n. 7.672/2010, aprovado na Câmara dos Deputados em 14.11.2011. O projeto prevê que pais que baterem em seus filhos sejam "encaminhados a programa oficial de proteção à família e a cursos de orientação, tratamento psicológico ou psiquiátrico, além de receberem advertência". Mas o art. 17 do ECA dispõe que "o direito ao respeito consiste na inviolabilidade da integridade física, psíquica e moral da criança e do adolescente". Segundo o relatório da Comissão Interamericana de Direitos Humanos (CIDH) da Organização dos Estados Americanos (OEA), de 2009, nas Américas, somente Uruguai, Venezuela e Costa Rica proíbem expressamente o castigo físico em suas legislações. Disponível em <http://cidh.oas.org/pdf\%20files/castigo\%20 corporal\%20portugues.pdf>. Acesso em 20 mai. 2013. No Canadá, surpreendentemente, mantém-se em vigor a seção 43 do Código Penal, a qual estabelece que um professor ou um pai pode fazer uso da força para corrigir um aluno ou um filho (The "Spanking" Law: Section 43 of the Criminal Code: Correction of child by force 43. Every schoolteacher, parent or person standing in the place of a parent is justified in using force by way of correction toward a pupil or child, as the case may be, who is under his care, if the force does not exceed what is reasonable under the circumstances). Disponível em <http://www.parl.gc.ca/content/lop/researchpublications/ prb0510-e.htm>. Acesso em 20 mai. 2013.

43 As exceções foram os Estados Unidos e a Somália. Diz-se que um dos principais motivos pelo qual os EUA assinaram a Convenção, mas não a ratificaram decorre do teor do art. $37^{\circ}$, alínea a, referente à proibição da cominação de pena de morte e prisão perpétua a menores de 18 anos, incompatível com o direito norte-americano. Outros países, embora tenham ratificado a Convenção, mantiveram uma posição de reserva, sobretudo os muçulmanos, e se recusaram a atribuir validade a alguns dispositivos, especialmente ao art. 14, que reconhece à criança o direito à liberdade religiosa. 
criança", segundo o qual os pais, os responsáveis, as instituições, as autoridades, os tribunais ou quaisquer entidades, ao tomarem decisões acerca de crianças, devem optar por aquelas que thes ofereçam o máximo de bem-estar $\left(\operatorname{art.} 3^{\circ}\right)^{44}$.

O princípio foi especialmente vertido para o texto constitucional no caput do art. 227. Assim, crianças e adolescentes têm sua dignidade assegurada não apenas de forma geral no art. $1^{\circ}$ da Constituição Federal, mas de forma específica no citado dispositivo ${ }^{45}$. Pela dicção do artigo, não há dúvida de que todos os direitos ali previstos têm a nota da fundamentalidade material ${ }^{46}$, que se dá justamente pela referência expressa à dignidade, assim como pela indicação do "lugar" prioritário, ocupado pela tutela das crianças, adolescentes e jovens (E.C. n 65/2010) na estrutura do Estado, da sociedade e da família, pois todos têm o dever de contribuir para a concretização dos direitos fundamentais daqueles. Eis aí uma responsabilização que bem se pode denominar "solidarista".

E ainda há tanto por fazer. Apenas para que se possa visualizar até onde chegam as repercussões das ações sobre o destino das crianças, um caso merece ser narrado ${ }^{47}$. Albie Sachs relata o famoso caso sul-africano em que o Tribunal Constitucional se decidia acerca da imposição de uma pena privativa de liberdade a M., mãe de três filhos

44 Na referência à criança, em documentos internacionais, normalmente se entende incluído o adolescente.

$45 \mathrm{CF}$, "Art. 227. É dever da família, da sociedade e do Estado assegurar à criança, ao adolescente e ao jovem, com absoluta prioridade, o direito à vida, à saúde, à alimentação, à educação, ao lazer, à profissionalização, à cultura, à dignidade, ao respeito, à liberdade e à convivência familiar e comunitária, além de colocá-los a salvo de toda forma de negligência, discriminação, exploração, violência, crueldade e opressão". Grifou-se.

46 CSarlet (2007) discorre acerca da fundamentalidade material e esclarece que ela resulta dos seguintes aspectos: i) os direitos fundamentais situam-se no ápice do ordenamento jurídico brasileiro; ii). na qualidade de normas constitucionais, encontram-se submetidos aos limites formais e materiais de reforma constitucional; iii) cuida-se de normas diretamente aplicáveis e que vinculam de forma imediata as entidades públicas e privadas. O ministro aposentado do Tribunal Constitucional sul-africano, Albie Sachs, considera o juiz "o contador de histórias do século XXI".

47 O ministro aposentado do Tribunal Constitucional sul-africano, Albie Sachs, considera o juiz "o contador de histórias do século XXI". 
menores $^{48}$. Seu voto inicial ao pedido fora no sentido de desconsiderá-lo completamente. No entanto, uma ministra insistiu que o caso merecia ser ouvido, argumentando: "E as crianças? A Sra. M. tem três filhos adolescentes. Ela vive em uma área de gangues, de tráfico de drogas e de grande violência. As indicações são de que ela é uma boa mãe, e o juiz não deu nenhuma atenção aos interesses das crianças, aos direitos humanos de seus filhos". Conta Sachs: "No minuto em que minha colega me falou sobre a importância dos três filhos adolescentes da Sra. M., comecei a vê-los não como três pequenos cidadãos que tinham o direito a crescer e se tornarem cidadãos adultos, mas como três garotos ameaçados, preocupados, frágeis e em conflito, que tinham um pedido à corte, um pedido à nossa sociedade como indivíduos, como crianças, e um pedido para não serem tratados apenas como extensões dos direitos da mãe, mas em seus próprios termos". Embora três juízes tenham dissentido do veredito majoritário, estabeleceu-se na África do Sul o precedente de que - ao menos em casos-limite - os cuidadores primários das crianças não devem ser presos. E se a corte decidir prender um cuidador primário, tem que assumir a responsabilidade pelo que acontecer às crianças. Finalizou o juiz: "A corte não pode simplesmente dizer que ela [a mãe] deveria ter pensado nisso antes de cometer o crime, ou que ela [a mãe] não pode se esconder atrás das crianças" 49 .

Até pouco tempo atrás, somente a África do Sul e a Escócia demonstravam preocupação com o destino dos filhos de mães

48 Entrevista a Jackie Kemp, 'Life Sentences', The Guardian, 1 July 2009, 5. Disponível em <http:// www.guardian.co.uk/society/2009/jul/01/albie-sachs-interview-childrens-rights>. Acesso em 15/05/2013.

49 No original: "The minute my colleague spoke to me about the importance of the three teenage children of Mrs. M, I started to see them not as three small citizens who had the right to grow up into big citizens but as three threatened, worrying, precarious, conflicted young boys who had a claim on the court, a claim on our society as individuals, as children, and a claim not to be treated solely as extensions of the rights of the mother, but in their own terms'. Although three judges dissented from the majority verdict, the precedent was set in South Africa that - at least in borderline cases - primary caregivers of children should not be sent to jail. And if the court decided to jail a primary caregiver, it had to take some responsibility for what happens to the children. 'The court can't simply say that she should have thought of that before she committed the offence, or that she can't hide behind her children". 
presidiárias. A boa notícia é que o Brasil passou a fazer parte desse pequeno grupo, através da Lei n. 12.403/2011, alterando o art. 318 do Código de Processo Penal (CPP) para permitir a substituição da prisão preventiva pela "prisão domiciliar nos casos de gestantes a partir dos sete meses" (inc. IV) ou para "resguardar cuidados imprescindíveis a crianças de até seis anos ou com deficiência” (inc. III). Há ainda, contudo, forte resistência à aplicação dessas medidas, vistas com desconfiança pela magistratura - porque, embora visem tão somente a proteção das crianças, favorecem, por via oblíqua, suas mães ${ }^{50}$. Inegavelmente, tal diploma legal representa mais um significativo passo na direção do cumprimento do comando constitucional da absoluta prioridade à dignidade, ao respeito, à liberdade e à convivência familiar assegurada às crianças no país (CF, art. 227, caput).

\section{A crise do conceito de incapacidade por idade}

Nas sociedades ocidentais, há, hoje, amplo consenso quando se pensa que os membros mais vulneráveis, os quais necessitam de garantias que atualmente só podem ser fornecidas pelo direito, são as crianças. Todavia, leis ditas protetivas continuam a se dirigir essencialmente às crianças abandonadas, hoje reputadas "em situação de rua". Para elas, o legislador prevê até mesmo o direito de "ir, vir e estar nos logradouros públicos (...)", em alegada proteção contra a sua institucionalização - direito certamente não reconhecido às crianças

50 Em julho de 2013, a Defensoria Pública obteve, perante o Tribunal de Justiça de São Paulo, liminares para garantir o direito à prisão domiciliar para duas mulheres - uma grávida de oito meses e outra mãe de um bebê de três meses. Ambas as decisões foram obtidas através de habeas corpus porque, apesar de a substituição de prisão preventiva por prisão domiciliar em casos de gestantes e mães ser um dispositivo considerado "claro", a maior parte dos magistrados não o têm aplicado. Para o Defensor Públicodo Núcleo Especializado de Situação Carcerária da Defensoria, Bruno Shimizu, "embora a Constituição garanta que a pena de uma pessoa não deve passar para outra, as crianças acabam nascendo em ambiente prisional e o sistema não tem equipe médica suficiente para o atendimento satisfatório". Notícia disponível no site Universo Jurídico, disponível em: <http://bit.ly/19INulQ>. Acesso em 11/07/2013. 
no âmbito familiar ${ }^{51}$. A propósito, recentemente, denunciou-se como "violadora dos direitos humanos" a política da Prefeitura do Rio de Janeiro que passou a realizar operações de recolhimento e internação compulsória para tratamento de crianças e adolescentes em situação de rua e fazendo uso de substâncias psicoativas (crack $)^{52}$.

Outra discussão surge quando se pensa em como garantir direitos fundamentais aos filhos, isto é, às crianças e adolescentes vistos através da opacidade do poder familiar. Para os autores que não adotam a metodologia do direito civil-constitucional, as coisas parecem um pouco mais fáceis: a distinção entre direito público e privado pode servir para diferenciar os meios de tutela próprios de um e de outro ambientes (STANZIONE, 2007), não se reconhecendo aos filhos sob a autoridade familiar a capacidade de exercer pessoalmente as liberdades previstas constitucionalmente. Tais autores aplicam ao caso dos filhos menores, essencialmente, como sempre foi, o disposto no art. 1.634 do Código Civil: "Compete aos pais, quanto à pessoa dos filhos menores: I - dirigir-Ihes a criação e a educação; (...) VII - exigir que lhes prestem obediência, respeito e os serviços próprios de sua idade e condição" 53 .

De fato, ainda há doutrinadores que entendem que a personalidade do filho menor não merece consideração autônoma e que sua tutela, dada a imaturidade natural dos menores, deve ser deixada aos adultos responsáveis. Essa é a opinião daqueles que se limitam a estampar os

51 V. o art. 16 do ECA. O assunto, por demais instigante, não poderá ser tratado nessa sede. Para uma crítica ao mencionado dispositivo, indica-se o editorial à civilistica.com a.1, n. 2, intitulado "O outro lado da rua".

52 Diferentemente do que poderia parecer, não são poucos os que condenaram a medida. V. a manifestação do Centro de Defesa dos Direitos da Criança e do Adolescente - CEDECA (Rio de Janeiro). Disponível em: <http://www.fundodireitoshumanos.org.br/v2/pt/projects/view/centro-dedefesa-dos-direitos-da-crianca-e-do-adolescente-cedeca-rio-de-janeiro?gclid=CLfmv4eYvrcCFe Nj7AodtE4ATg>. Acesso em 20 jan. 2013.

53 Interessante fenômeno, paralelo à assunção do papel central pela criança na família, reside na formação da chamada geração $Y$, composta por pessoas (nascidas entre os anos de 1980 a 2000) cuja educação e criação, quando crianças, constituíram o centro das preocupações familiares, e que, diversamente das gerações anteriores, não encontraram em seus pais modelos ou referências, mas, ao contrário, desde cedo tiveram suas individualidades supervalorizadas. Algumas características dessa geração são comentadas em BODIN DE MORAES, Maria Celina. Por um ensino humanista do direito civil. civilistica.com. a. 1, n. 2, 2012. 
dispositivos legais sobre a incapacidade, sem tecer maiores comentários sobre eles. A consequência implícita é a correlata impossibilidade do exercício pessoal de direitos, patrimoniais ou não patrimoniais, a não ser que a lei expressamente o permita. A esse respeito, vale salientar que, no direito nacional, os maiores de 16 anos não se consideram passíveis de representação legal ${ }^{54}$, mas de assistência - vale dizer, o legislador entende que são dotados de vontade juridicamente relevante, embora ainda não completamente madura. Cabe notar ainda que, mesmo sob a égide do Código Civil de 1916, já Ihes era reconhecida a capacidade de exercer uns poucos direitos individualmente - que, aliás, continuam os mesmos no Código atual: podem fazer testamento (art. 1.860, parágrafo único), aceitar mandato (art. 666) e prestar testemunho (art. 228 CC). Como mais recente novidade, o CNJ instituiu um provimento no qual estabeleceu que o reconhecimento da paternidade pelo pai relativamente incapaz independe de assistência ${ }^{55}$.

Todavia, a própria Convenção Internacional dos direitos da criança, na já longínqua década de 80 do século passado, previu, em seu art. 12, uma regra expressa que ainda temos dificuldade em aplicar, presos que estamos à literalidade dos artigos $3^{\circ}$ e $4^{\circ}$ do Código Civil. O art. 12.1 da Convenção dispõe que os "Estados Partes devem assegurar à criança que é capaz de formular seus próprios pontos de vista o direito de expressar suas opiniões livremente sobre todos os assuntos relacionados a ela, e tais opiniões devem ser consideradas, em função da idade e da maturidade da criança"56.

\footnotetext{
54 Vale notar que os anteprojetos de Código Civil da década de 1960, de Orlando Gomes (1963) e revisto pelo autor, juntamente com Caio Mário da Silva Pereira e Orosimbo Nonato (1964), indicam o início da incapacidade relativa a partir de 15 e 14 anos, respectivamente. Foi o Anteprojeto de 1972, revisto em 1973, que determinou o retorno à idade prevista no Projeto Beviláqua (1899).

55 Provimento n. $16 / 2012$ do $\mathrm{CNJ}$, art. $6^{\circ}, \S^{\circ}$.

56 O art. 227 da Constituição é justamente o resultado dessa inflexão hermenêutica sobre a relevância do exercício dos direitos pela criança e pelo adolescente. Tamanha é a inovação quanto ao tratamento da população infanto-juvenil que a Constituição dedica à criança e ao adolescente um dos mais expressivos textos consagradores de direitos fundamentais da pessoa humana, cujo conteúdo foi, posteriormente, explicitado pelo Estatuto da Criança e do Adolescente.
} 
Desde então, fortaleceu-se uma nova corrente, uma terceira via, que se põe entre os intervencionistas e os não intervencionistas, sustentando a efetividade do exercício dos direitos fundamentais aos menores, conforme sua maturidade; posição que pode ser definida como a da extensão da capacidade de fato no que toca a interesses, prerrogativas e direitos, via de regra, não patrimoniais. A Convenção não dá indicações em relação ao fator idade, embora se considere que, evidentemente, esse é um parâmetro inelutável no caso concreto ${ }^{57}$.

O processo de democratização da família indica que a vida familiar deve conseguir combinar escolhas individuais e solidariedade familiar. A democracia, nesse contexto familiar, implica igualdade, respeito mútuo, autonomia, proteção contra a violência e integração social. Quanto aos filhos, os relacionamentos familiares democráticos ensejam responsabilidade compartilhada pelo cuidado da criança, especialmente com maior partilha de direitos e deveres entre pais e mães. Mais importante, os pais não mais têm a missão de transformar seus filhos em função de princípios exteriores; a autoridade parental dilui-se na noção de respeito à originalidade da pessoa do filho, valorizando-se qualidades outras que não a obediência e o respeito. Os pais colocamse na posição de ajudar os filhos a se tornarem seres autônomos ${ }^{58}$, devendo isso ser considerado o conteúdo atual do princípio do melhor interesse da criança e do adolescente.

Um obstáculo ao modelo democrático de família pode estar no desempenho da função parental de modo autoritário. Hoje, mais do que antes, é preciso traçar uma linha divisória entre o exercício legítimo da potestade e os espaços de autonomia e autodeterminação

57 A propósito do exercício pessoal de direitos fundamentais, veja-se a solução do Código Civil espanhol, o qual estabelece, em seu art. 154, a obrigação dos pais de representarem seus filhos enquanto são menores de idade, mas exclui da possibilidade de representação, expressamente no art. 162, os "atos relativos aos direitos pessoais ou outros que a criança, de acordo as leis e o seu grau de maturidade, pode fazer por si mesma". V., ainda, João Baptista Villela. O fim das menoridades. Vídeo disponível on-line.

58 Nas palavras de Luís Fernando Veríssimo (Referência?): "A verdade é que a gente não faz filhos. Só faz o layout. Eles mesmos fazem a arte final". 
do filho como sujeito de direitos fundamentais. O problema maior não diz respeito à proteção patrimonial do filho menor, já controlada pelo legislador e pelo juiz, e sim ao exercício de seus direitos na esfera existencial. Essa esfera, "território de formação da personalidade de um indivíduo", não só tem mais relevo hoje, depois de passar pelo processo da despatrimonialização do direito civil ${ }^{59}$, como também constitui o cenário em que "o poder educativo parental tem um papel determinante" (BALLARINI, 2010, p. 475).

Ouçamos, a propósito, a opinião de uma grande e experiente psicanalista infantil:

Quando se ensinará às crianças que são fundadas as suas observações sobre as contradições entre dizer e agir nos adultos, entre os deveres deles, segundo a lei escrita, e os direitos que se arrogam? Quando serão elas cumprimentadas por exercerem sua inteligência na compreensão do relativo em todas as coisas e da necessidade de contestação e de conflitos de julgamento e de opiniões? (...) Se não quisermos que nossa sociedade, chamada ocidental, soçobre, não deverá ser aos dezoito anos a idade da maioridade e do ingresso por direito na vida produtiva e na plena responsabilidade pelos atos pessoais, mas aos quinze, dezesseis no máximo, que os jovens deveriam ter o direito de libertar-se da tutela paterna, tão frequentemente abusiva. Mas, para isso, deveriam ser ministrados às crianças dos sete aos quinze anos uma outra educação e um outro ensinamento do saber necessário à conduta. (...) Inseri-los bem cedo, se assim desejarem - e muitos desejam e seriam capazes -, em responsabilidades de cidadãos. Quanta solidão e quanta aflição infantil, decorrentes do sentimento de ser inútil e de não ter comunicação, seriam assim poupadas! Quanto sofrimento das crianças se deve a sentimentos de culpa por atos e comportamentos sadios, que incomodam a tranquilidade dos adultos, pura e simplesmente. (DOLTO, 1998, p. 115).

59 Por todos, v. PERLINGIERI, Pietro. Depatrimonializzazione e diritto civile. Rassegna di diritto civile, 1983, p. 1 e ss. 
Com efeito, torna-se imperativo reconhecer a capacidade de ação dos menores, embora ainda sujeitos ao poder familiar, para o exercício dos seus direitos fundamentais, devendo-se, nesses casos, no mínimo, inverter a presunção de capacidade (e não mais de incapacidade), mesmo porque, como se sabe, ela é a regra (sendo exceção a incapacidade). Visa-se compartilhar esse saber já há muito consolidado ${ }^{60}$ para 0 incremento de um consistente pensamento jurídico no que tange às relações paterno-filiais, em que às crianças e aos adolescentes deve ser atribuída, como titulares de direitos, a capacidade do seu exercício, em prol da realização de seus interesses, através de prerrogativas e direitos específicos. Tudo isso em direta oposição à concepção que ainda os reduz a meros sujeitos-objeto de direito, que se sujeitam às escolhas de outrem - essencialmente dos pais e, na falta de acordo entre eles, do juiz - e demandam, passivamente, assistência moral e material, proteção e limites. Trata-se, em última análise, do reconhecimento da "pessoa da criança".

Para o bom cumprimento da função parental, vale ressaltar, dispensa-se a convivência infeliz do casal na criação dos filhos. A saúde do indivíduo tem uma conotação ampla, dita pela Organização Mundial da Saúde "biopsicossocial", e depois que danos severos foram causados à pessoa na infância, é como se um indivíduo saudável não mais pudesse florescer: sua contribuição, seja na família, seja na

60 Sintetiza com excelência Freeman (1997, pp. 366-367): “A distinction between adults and very young dependent children is obviously needed. Yet distinctions which are too rigid and sweeping, which attribute all wisdom, knowledge and prudence to adults, and all folly, ignorance and selfdestructiveness to children, do not fit true reality. And history (Aries, 1962; Cunningham, 1991), sociology (James and Prout, 1990; Qvortrup et al, 1994; Brannen and O'Brien, 1996; Jenks, 1996), psychology (Melton, 1987; Stainton Rogers, 1992); education (Alderson, 1993), as well as developments within the law (see, in particular, the Gillick decision) pose a challenge to the [that] concept of childhood". E destaca: "There has been important work on children's competence. Weithorn and Campbell compared the responses of nine, fourteen, eighteen and twenty-one-year-old participants to hypothetical decision-making problems concerning medical and psychological treatment. The fourteen-year-olds did not differ from the adult groups on any of the major standards of competency to consent: evidence of a choice; understanding of the facts; reasonable decision-making processes; reasonable outcome of choice. Even the nine-year-olds were as competent as the average adult, according to the standards of evidence of a choice and reasonableness of choice. (Weithorn and Campbell, 1982)". 
sociedade, resta permanentemente prejudicada. (WINNICOTT, 1999) De nada adiantam as sanções tradicionais do direito de família: a perda ou a suspensão do poder familiar são vistos com alívio pelos maus pais, que dessa forma se desresponsabilizam em definitivo pelo filho.

O Poder Judiciário, mostrando-se mais uma vez atento à realidade, vem buscando minorar os prejuízos e aumentar as chances de conciliação. A propósito, o Comitê do Movimento pela Conciliação do $\mathrm{CNJ}$, que tem por objetivo diminuir o ajuizamento de ações nos tribunais, começou, em 2012, a apoiar o projeto intitulado "Oficinas de Parentalidade", voltado ao fornecimento de instrumentos e suporte aos casais, para que não usem o divórcio como vingança. Nesse último caso, como se sabe, as crianças viram "pedras", atiradas que são, de um lado para o outro. O divórcio, então, passa a ser visto como "uma nova fase na vida do casal, uma continuação, pois continuarão sendo uma família, mas com uma formação diferente" ${ }^{\text {61 }}$.

As primeiras experiências desse "divórcio conciliado" ocorreram na Bahia, no Distrito Federal e no Rio de Janeiro, e hoje o procedimento está em expansão62. Seu principal objetivo é justamente a responsabilização do casal em relação ao seu futuro e ao de sua prole. "As pessoas passam a se sentir responsáveis e autônomas, pois não é um juiz que vai resolver quem está certo e quem está errado, mas os envolvidos é que chegarão à melhor solução" (BOIN AGUIAR, 2009). Entretanto, um dos aspectos mais relevantes do projeto é que a autocomposição - através da conciliação ou da mediação - não substitui o julgamento.

61 Assim se pronuncia o juiz André Gomma de Azevedo, que defende pensar o Judiciário como um hospital de resoluções de conflitos, e não mais como uma instituição que apenas impõe decisões às partes. Notícia disponível em: <http://www.cnj.jus.br/noticias/judiciario/23503-tjsp-promovetreinamento-funcional-para-oficina-de-parentalidade>. Acesso em 21 mar. 2013.

62 Recentemente, foi realizado no TJSP o primeiro treinamento do divórcio conciliado, com palestra proferida pelo juiz André Gomma de Azevedo, que tem viajado pelo Brasil, em nome do CNJ, proferindo cursos para formar conciliadores e mediadores. Dirigindo-se a cerca de 200 assistentes sociais e psicólogos das Varas de Família e Sucessões e da Infância e Juventude da capital, o magistrado salientou que "nenhum outro jurisdicionado 'bate de frente' com o juiz como o jurisdicionado da área da família, que não aceita cumprir a decisão judicial porque as partes estão muito envolvidas", preocupadas com o andamento e com o resultado das decisões. 
Esse é um dos pontos-chave para que os magistrados aceitem que haja conciliação e mediação nas varas em que trabalham; aliás, "convencer os juízes da necessidade de se implantar centros de mediação ou de conciliação é um dos grandes degraus a serem superados"63.

\section{O movimento em direção à maior autonomia nas relações conjugais}

Tecidos os comentários anteriores sobre a responsabilidade e a função da família (além do Estado e da sociedade) de zelar pelo crescimento saudável das crianças, cumpre fazer algumas considerações sobre o outro extremo do processo da democratização familiar e verificar quão crescente é (ou deve ser) o espaço de autonomia na família. A passagem, já tantas vezes referida, da família como instituição à família instrumental - aquela que propicia um ambiente adequado ao desenvolvimento da personalidade de todos e de cada um de seus membros - suscitou, indiscutivelmente, a ampliação de espaços para a individualização e, em consequência, a maior autonomia da pessoa na esfera familiar.

Essa autonomia individual realça a atual instabilidade dos casamentos e é por ela reforçada, em um processo circular decorrente da maior liberdade de escolhas, especialmente no que tange à estrutura familiar mais conveniente. A normalidade do divórcio - mais bem evidenciada no ordenamento brasileiro após a Emenda Constitucional n. 66/2010, que excluiu a necessidade de qualquer lapso temporal como etapa intermediária à obtenção do divórcio - gerou, evidentemente, consequências para o sistema familiar como um todo, passando o casamento a representar tão somente a realização de projetos exclusivamente individuais, e não mais, como antes, "um assunto pertencente ao amplo universo dos parentescos" (VELHO, 2001).

63 Notícia disponível em: <http://areopagobr.blogspot.com.br/2012_10_01_archive.html>. Acesso em 20 mai. 2013. 
A constitucionalidade do casamento homossexual veio impor novos e mais complexos desafios ${ }^{64}$. Com efeito, a decisão abala as raízes do instituto, cuja tradição é fortemente religiosa. Mais importante: a constitucionalidade também gera relevantes efeitos sobre a forma como sempre se entendeu - juridicamente, pelo menos - a filiação: um triângulo composto por um único pai e uma única mãe em relação ao filho. Com o advento do casamento entre pessoas do mesmo sexo, a parentalidade não pode mais ser regulada com base no princípio da "unicidade" - um pai e uma mãe -, como tem sido nas sociedades ocidentais ${ }^{65}$. Em consequência, por exemplo, uma criança, se filha de um casal de mulheres, terá em sua certidão de nascimento66 apenas a devida referência às mães e nenhum espaço para a identificação do pai, em princípio inexistente67, a não ser que decidam diversamente. $\mathrm{E}$ vice-versa.

A propósito, o Conselho Federal de Medicina (CFM) aprovou a Resolução n. 2.013, publicada em 9 de maio de $2013^{68}$, que, ao indicar as normas para a utilização das técnicas de reprodução assistida (RA), estende a todas as pessoas o direito de recorrer ao procedimento, estabelecendo como requisito unicamente a capacidade plena (Item II,

64 Países que atualmente adotam o casamento homossexual, além do Brasil, são os seguintes: África do Sul, Argentina, Bélgica, Canadá, Dinamarca, Espanha, França, Islândia, Holanda, Noruega, Nova Zelândia, Portugal, Suécia e Uruguai. Numerosos outros países reconhecem a união civil entre pessoas do mesmo sexo.

65 Embora essa seja ainda uma questão sensível em alguns países, como o Canadá (onde a adoção é proibida) e a França, havendo grandes manifestações contrárias a essa possibilidade. O Brasil admite o casamento, a adoção e a reprodução assistida a casais do mesmo sexo: v. infra.

66 Aproveita-se a oportunidade para sugerir, juntamente com as mudanças que ocorrerão nos registros de nascimento, que se institua um espaço para o CPF dos pais, de modo a facilitar sua identificação.

67 A recém-promulgada Resolução CFM n. 2.013/2013, que regulamenta a adoção das técnicas de reprodução assistida também para os casais homossexuais, estabelece expressamente que "os doadores não devem conhecer a identidade dos receptores e vice-versa" (Item IV, 2) e que "obrigatoriamente será mantido o sigilo sobre a identidade dos doadores de gametas e embriões, bem como dos receptores. Em situações especiais as informações sobre doadores, por motivação médica, podem ser fornecidas exclusivamente para médicos, resguardando-se a identidade civil do doador"(Item IV, 4).

Documento disponível em <http://portal.cfm.org.br/>. Acesso em 02 jun. 2013. 
1) ${ }^{69}$. A regulamentação anterior deixava margem a dúvidas e, por isso, a nova resolução explicita o direito aos casais do mesmo sexo (Item II, 2), o que poderá ocorrer da seguinte maneira: nos casais formados por mulheres, uma delas poderá ter seu óvulo fecundado e ela mesma continuar a gravidez ou, se preferir, o seu óvulo pode ser implantado no útero da parceira ou de parente. Já nos casais formados por homens, será necessário o consentimento de parente para levar adiante a gestação. A resolução estabelece que a "gestação de substituição" ou "doação temporária do útero" deve provir da família de um dos parceiros em "parentesco consanguíneo até o quarto grau" (Item VII, 1) e "a doação temporária do útero não pode ter caráter lucrativo ou comercial" (Item VII, 2), prevendo, ainda, dentre os documentos necessários, um "contrato entre os pacientes (pais genéticos) e a doadora temporária de útero (que recebeu o embrião em seu útero e deu à luz), estabelecendo claramente a questão da filiação da criança", bem como "a garantia do registro civil da criança pelos pacientes (pais genéticos), devendo tal documentação ser providenciada durante a gravidez". Previu-se, enfim, que "se a doadora temporária de útero for casada ou viver em união estável, deverá apresentar, por escrito, a aprovação do cônjuge ou companheiro" (Item VII, 3) $)^{70}$.

Como exemplo das novas famílias que surgirão, Andrew Solomon, famoso escritor americano, conta como é a sua:

meu marido é o pai biológico de duas crianças (Oliver e Lucy) com amigas lésbicas em Minneapolis. Eu tinha uma

69 As demais novidades da resolução são a regulamentação do destino de embriões congelados há mais cinco anos (descarte ou destinação a pesquisas de células-tronco, segundo a vontade dos pacientes), o estabelecimento de uma idade limite (50 anos) para recorrer às técnicas de fertilização in vitro e a normatização da chamada "doação compartilhada", quando os óvulos de uma mulher são usados por ela e por outra para engravidar. A doação compartilhada já era praticada nas clínicas, mas ainda não havia sido regulamentada. Pela resolução, doadores não podem conhecer a identidade dos receptores e vice-versa; e a idade limite para doação de gametas é de 35 anos para mulheres e 50 anos para homens. Além disso, admite expressamente a reprodução assistida post-mortem, "desde que com autorização prévia específica do falecido ou da falecida".

70 A mera leitura da resolução já indica que não ficará isenta de polêmicas. 
amiga de faculdade que havia se divorciado, mas queria ter filhos. E, assim, eu e ela temos uma filha, e mãe e filha vivem no Texas. Meu marido e eu temos um filho, que vive conosco, do qual eu sou o pai biológico, cuja gravidez foi de Laura, a mãe lésbica de Oliver e Lucy em Minneapolis. Em resumo, somos cinco pais de quatro crianças em três estados. (...) Há pessoas que pensam que a existência de minha família de alguma forma prejudica ou enfraquece a sua família. Há pessoas que pensam que famílias como a minha não devem existir. Eu não aceito modelos de subtração de amor, apenas modelos de adição e acredito que, da mesma forma que precisamos da diversidade de espécies para garantir que o planeta continue a existir, precisamos também da diversidade de afetos e de famílias, a fim de fortalecer a biosfera da bondade e da benevolência (kindness) ${ }^{71}$.

Diante de tão profundas mudanças, o instituto do casamento, que permanece como o ato mais solene do direito civil, parece cada dia mais anacrônico ${ }^{72}$, inclusive do ponto de vista jurídico, cabendo questionar se é justificável a manutenção de disciplina tão formal e minuciosa. A perda de seu caráter único, constitutivo da família, mudou a qualidade, a natureza e o significado do casamento, "tornando-o menos abrangente e forte em suas implicações sociológicas" (VELHO, 2001). Além disso, verificou-se, de um lado, uma quase completa equiparação com a união estável, podendo-se dizer que, para além de pequenos e desimportantes detalhes, a grande diferença entre um e outro passou a ser a de que se pode considerar o casamento um tipo de "prova pré-constituída" (se houve casamento, as consequências seguem o ato; se não houve casamento, primeiro será preciso verificar se houve união estável que, portanto, deverá restar provada - para então se aplicarem seus

\footnotetext{
71 SOLOMON, Andrew. "Love, no matter what". TED. Vídeo disponível em <http://www.ted.com/ talks/ andrew_solomon_love_no_matter_what.html>. Acesso em 6 jun. 2013.

72 E aqui é inevitável lembrar a sutil ironia machadiana: "Deus, para a felicidade do homem, inventou a fé e o amor. O Diabo, invejoso, fez o homem confundir fé com religião e amor com casamento". Referência?
} 
efeitos, praticamente idênticos nos dois casos). De outro lado, ocorre a impopularidade do casamento homossexual - que, pelo mero uso da palavra "casamento", enfrenta forte oposição de organizações religiosas de todos os credos $^{73}$.

Assim sendo, cabe questionar se devem ser mantidas tantas e tão detalhadas regras, provenientes de um tempo em que o casamento representava o eixo central da família, do qual todas as demais relações familiares derivavam: seja a regulamentação da vida em comum, seja a legalidade do parentesco, seja a licitude das relações íntimas. Já se sabe que ele perdeu todas essas funções: não serve mais para legitimar filhos, garantir estabilidade familiar, proteger direitos hereditários e mal serve para presumir a parentalidade ${ }^{74}$. A maioria dos direitos do cônjuge tem sido estendida ao companheiro. Aliás, a tutela jurídica que famílias simultâneas vêm recebendo é outro indício do diminuto valor sociocultural do casamento - e, em consequência, também de seu valor jurídico -, incluindo-se a decrescente relevância do próprio princípio da monogamia. Entre os tantos exemplos, indica-se apenas o mais recente: em maio de 2013, a Terceira Turma do STJ considerou admissível que a impenhorabilidade do bem de família atinja simultaneamente dois imóveis do devedor - aquele onde ele mora com sua esposa e outro no

73 Essa rejeição, diversamente do que normalmente ocorre, não parece ser particularmente forte no país, de ampla maioria religiosa - embora quanto à parentalidade permaneça a incerteza. A pesquisa do reconhecido Pew Research Center revela que o mundo está dividido sobre o casamento gay, sendo a religiosidade do povo o fator determinante. A pesquisa mostra que a tolerância cresce à medida que a população é menos religiosa. No entanto, algumas significativas exceções fizeram-se notar: em países como a Rússia e a China, que têm níveis de religiosidade baixos, a aceitação do casamento homossexual é baixa, de $16 \%$ e $21 \%$, respectivamente; inversamente, no Brasil e nas Filipinas, países com alto nível de religiosidade, há forte aceitação do casamento entre pessoas do mesmo sexo. Entre 0 e 3 pontos em nível de religiosidade, o Brasil tem pouco mais de 2, ou seja, um dos países com maior taxa de importância da religião na sociedade e, ainda assim, $60 \%$ dos entrevistados afirmam ser a favor da união homoafetiva. Pesquisa disponível em: <http://www.pewglobal.org/2013/06/04/the-global-divideon-homosexuality/>. Acesso em 5 mai. 2013.

74 Contra a presunção, por ferir o princípio da isonomia constitucional, entre outros, v. TABET, Gabriela. A inconstitucionalidade da presunção pater is est. Revista trimestral de Direito Civil. Rio de Janeiro, v. 6, n. 22, pp. 71-95, abr./jun. 2005. Com o mesmo fundamento, outros defendem sua ampliação: assim, v. Cristiano C. de FARIAS e Nelson ROSENVALD. Direito das famílias. Rio de Janeiro: Lumen Juris, 2008, p. 498. 
qual vivem suas filhas nascidas de relação extraconjugal ${ }^{75}$. $\mathrm{O}$ recurso fora interposto pelo Ministério Público, contra decisão do Tribunal de Justiça de Minas Gerais, que, por maioria, decidira que a garantia legal da impenhorabilidade só poderia recair sobre um único imóvel, onde o devedor residisse com sua família, porque a relação concubinária do devedor não pode ser considerada entidade familiar nos termos da legislação em vigor ${ }^{76}$.

Se hoje os benefícios do casamento civil se mostram duvidosos, há um inegável efeito nefasto que precisa ser levado em conta. Tratase de uma instituição que divide as pessoas em duas categorias: uma muito rígida - os casados - e outra residual - os solteiros (THALER e SUNSTEIN, 2008). Como se sabe, a união estável, não obstante sua força igualitária, jamais conseguiu obter um estado civil próprio: o estado de companheiro não passou de projeto de lei, o que relega os conviventes ao lado mais improvável e constrangedor da divisão - a categoria dos solteiros, estado civil evidentemente inaplicável à sua realidade, seja do ponto de vista patrimonial, seja do ponto de vista existencial.

O relacionamento conjugal democrático demanda "o envolvimento dos indivíduos na determinação das condições de sua associação" e se aplica não apenas ao início de uma relação, mas "também à reflexividade

75 STJ. 27.05.2013. "STJ amplia o conceito de entidade familiar para proteção de bem de família". Disponível em:<http://www.stj.jus.br/portal_stj/publicacao/engine.wsp?tmp.area=398\&tmp. texto=109776\&utm_source=agencia\&utm_medium =email\&utm_campaign=pushsco $>$. Acesso em 30 mai. 2013.

76 STJ, 4 ${ }^{a}$ T., REsp. 912.926, Rel. Min. Luís Felipe Salomão, publ. em 07.06.2011, em cuja ementa se lê: "Direito de família. Reconhecimento de uniões estáveis simultâneas. Impossibilidade. Exclusividade de relacionamento sólido. Condição de existência jurídica da união estável. Exegese do $\S 1^{\circ}$ do art. 1.723 do Código Civil de 2002. 1. Para a existência jurídica da união estável, extrai-se, da exegese do $\S 1^{\circ}$ do art. 1.723 do Código Civil de 2002, fine, o requisito da exclusividade de relacionamento sólido. Isso porque, nem mesmo a existência de casamento válido se apresenta como impedimento suficiente ao reconhecimento da união estável, desde que haja separação de fato, circunstância que erige a existência de outra relação afetiva factual ao degrau de óbice proeminente à nova união estável. 2. Com efeito, a pedra de toque para o aperfeiçoamento da união estável não está na inexistência de vínculo matrimonial, mas, a toda evidência, na inexistência de relacionamento de fato duradouro, concorrentemente àquele que se pretende proteção jurídica, daí por que se mostra inviável o reconhecimento de uniões estáveis simultâneas." 
inerente à sua continuação - ou a sua dissolução" (GIDDENS, 1993, p. 207). Mais recentemente, propuseram a desregulamentação legal dos relacionamentos conjugais dois estudiosos americanos, favoráveis ao que chamam de "privatização do casamento"77, sustentando que o Estado deveria sair de cena e não mais tutelar as relações conjugais através de normas imperativas (THALER e SUNSTEIN, 2008), mas tão somente mediante regras supletivas ("standards") em caso de não manifestação expressa do casal. Argumentam que a "licença para casar", se já foi fundamental tanto para manter relações sexuais licitamente quanto para obter legitimamente a prole, hoje, ao contrário, serve para institucionalizar a desigualdade, criando a oportunidade de se estabelecerem dois grupos (os casais casados e os casais não casados). Eventualmente, cada vez que um grupo obtiver direitos especiais, o outro quererá se igualar, salvo se o objetivo for instituir e manter na sociedade diferentes "castas". Diante dessa realidade, será realmente oportuno continuar a regular apenas uma das categorias e, o que é pior, por meio de normas cogentes?

De qualquer forma, sustentam os autores que separar a cerimônia, religiosa ou não, da regulamentação da vida em comum traria vantagens, especialmente para as mulheres - que, com a separação, ficam geralmente em situação econômica inferior à dos ex-maridos. Nessa hipótese, com a dissociação entre a cerimônia, especialmente se religiosa, e uma eventual escritura de pacto nupcial, o próprio casal regulamentaria (talvez de forma mais cuidadosa) sua relação. Nessa proposta, salientam os autores, há a adicional vantagem de que as religiões poderiam regular os próprios casamentos, atribuindo requisitos e consequências de acordo com seus costumes e suas tradições,

\footnotetext{
77 Ainda em 1997, David Boaz indagava, retoricamente, por que o governo deveria determinar quem pode e quem não pode se casar. V. "Privatize Marriage: A Simple Solution to the GayMarriage Debate". Disponível em <http://www.slate.com/id/2440/April 1997>. Acesso em 30 mai. 2013. Em novembro de 2007, o The New York Times publicou um interessante artigo de opinião de Stephanie Coontz, intitulado "Taking Marriage Private", que conta um pouco da história da instituição e mostra como ela já foi regulada das mais diversas formas. Disponível em <http:// www.nytimes.com/2007/11/26/opinion/26coontz.html?_r=3\&em\&ex=1196226000\&en=5e70532fc e256fe0\&ei=5087\%0A\&oref=slogin\& >. Acesso em 31 mai. 2013.
} 
tais como o efeito da indissolubilidade da relação e o requisito da diferença entre os sexos. Seriam diferenciações, e não discriminações, consideradas próprias de cada organização religiosa (THALER E SUNSTEIN, 2008).

Um recente caso exemplifica o que se buscou mostrar acerca do valor atual das relações conjugais formais em nossa sociedade. Um corretor de seguros tinha uma agenda de modestos, mas fiéis clientes. Em certa ocasião, para atingir a quota de produção que, pelo volume mensal, garantiria um bônus salarial, contratou, como segurado, um seguro de vida para si mesmo. Solteiro e sem qualquer relação estável definida como exclusiva, ele indicou como beneficiária "a esposa". Morreu de infarto e, pouco tempo depois, três postulantes se apresentaram na seguradora, devidamente munidas com documentos que registravam flashes da vida em comum: fotografias, notas de hotéis e contas de luz, água e telefone em nome do falecido, em três endereços diferentes. $\mathrm{O}$ setor jurídico da seguradora optou por uma ação de consignação em pagamento diante das pretendentes. O juiz sentenciou pelo pagamento integral em favor de uma delas - a que mantivera a "relação estável por mais tempo". Apenas a segunda das três apelou da decisão. Mesmo sem o recurso das demais, no Tribunal de Justiça do Rio Grande do Sul, o relator propôs uma divisão igualitária. O vogal e a revisora invocaram um empecilho processual: como fazer a divisão de $33,33 \%$ para cada companheira se uma delas se conformara com a sentença que nada lhe destinara? O relator, porém, insistiu na solução salomônica, os demais logo capitularam e assim foi lavrado o acórdão ${ }^{78}$.

\section{Conclusão}

"Não há bom pai, essa é a regra. Não é uma questão de culpa dos homens, é o próprio vínculo da paternidade que é podre. Fazer crianças,

78 Disponível em: <http://www.espacovital.com.br/noticia_ler.php? id=29612>. Acesso em 25 mai. 2013. 
nada melhor. Tê-las, que tortura! Tivesse vivido, meu pai teria se deitado sobre mim em todo o seu comprimento e me teria esmagado. Por sorte, morreu cedo"79. O autor dessas palavras, Jean-Paul Sartre, segundo seus biógrafos, passou a vida escrevendo ao pai morto na guerra, buscando uma forma de diminuir tanto a falta quanto seu ressentimento com a morte precoce pela qual o culpava. Com efeito, em Sartre, "a figura do pai, condenado a permanecer imaginário, é onipresente: podese, portanto, ler Le scénario Freud, Les mots e L'idiot de la famille como uma verdadeira trilogia da paternidade" (CHABOT, 2012, p.?).

Já Freud (Referência?) afirmou "não conseguir imaginar uma necessidade mais forte na infância do que a proteção de um pai". Pesquisas recentes felizmente confirmam "o caráter social, histórico, cultural e político da paternidade" e são, pois, concretas as possibilidades do exercício de uma "paternidade-cidadã", com o pai constituindo-se "como promotor da igualdade de direitos e de oportunidades na fratria" $\left(\right.$ THURLER, 2012, p. 117) ${ }^{80}$. Mais uma vez, ecoam as palavras de Winnicott: "são os bons lares comuns que fornecem o único contexto em que se pode criar o fator democrático inato" (GARCIA, 2011, p.?). Para a criação e manutenção de ambientes favoráveis ao pleno desenvolvimento da pessoa humana, a responsabilidade com as crianças precisa ser solidarista, isto é, assumida pelo Estado, pela sociedade e pela família - por todos, precisamente como determina a Constituição no art. 227, e como deve ser em uma sociedade que pretende tornar-se justa e solidária.

Há algum tempo, ao final de um artigo intitulado "A família democrática", fez-se alusão a alguns tópicos que, embora não exaurissem todos os problemas, pareciam clamar pelas mudanças mais urgentes em prol do aperfeiçoamento de relacionamentos

79 No original : "Il n'y a pas de bon père, c'est la règle; qu'on n'en tienne pas grief aux hommes mais au lien de paternité qui est pourri. Faire des enfants, rien de mieux; en avoir, quelle iniquité! Eût-il vécu, mon père se fût couché sur moi de tout son long et m'eût écrasé. Par chance, il est mort en bas âge."

80 Principalmente agora, com o instrumental garantido pela guarda compartilhada e pela Lei SAP Síndrome de Alienação Parental. 
intrafamiliares democráticos. Todos se baseavam em desigualdades materiais - algumas também jurídicas - mais ou menos significativas. O primeiro aspecto, e mais importante, era (e, infelizmente, continua sendo) a violência contra a mulher. Seguiam-se-lhe os problemas da guarda unilateral, da idade estabelecida para a separação obrigatória de bens, da imprescritibilidade da ação negatória de paternidade e, enfim, da lamentável manutenção da culpa na separação. Por incrível que pareça, poucos anos depois, a maioria dos problemas indicados mostra-se resolvida do ponto de vista teórico: em primeiro lugar, promulgou-se uma boa lei contra a violência doméstica; em seguida, a guarda compartilhada foi instituída como padrão na ausência de acordo diferente entre os cônjuges; o regime da separação de bens passou a ser obrigatório somente aos 70 anos; enfim, a imprescritibilidade prevista no art. 1601 esvaziou-se com a interpretação dada pelo STJ à negatória ${ }^{81}$, ao mesmo tempo em que, com a possibilidade da pluralidade paterna e materna (conquista implícita à filiação no casamento homossexual), os filhos "negados" (ou não-filhos, nas palavras de Fachin ${ }^{82}$ ) não mais perdem, necessariamente, o vínculo parental, pois continuam a ter direito à paternidade socioafetiva.

Embora haja razões para comemorar, é difícil dizer se se chegará a um patamar de estabilidade. As reformas em matéria de família parecem ser infindáveis, e por uma razão pessimista: trata-se de ramo do direito que cuida, em síntese, da distribuição das perdas no âmbito de nossas vidas privadas. Quando a família precisa encontrar o direito, não há vencedores (PARKINSON, 2011). Além disso, é como reza o dito popular: "quando a gente pensa que sabe todas as respostas, a vida muda as perguntas".

O reconhecimento do caráter instrumental da família para o desenvolvimento de seus membros era, até recentemente, tido como o avanço fundamental do direito de família. Hoje, estranhamente, dizer

\footnotetext{
81 Ver nota 41, supra.

82 FACHIN, Luiz Edson. As intermitências da vida: o nascimento dos não filhos à luz do Código Civil brasileiro. Rio de Janeiro: Forense, 2007.
} 
tanto ainda significa dizer pouco. Torna-se imprescindível considerar a família com novos olhos, atentando para seu uso disfuncional, para as raízes dessa disfunção e para o papel promocional que o direito pode desempenhar em sua prevenção. Se atualmente se afirma que a relação conjugal pode ser uma questão privada entre dois adultos - a ser resolvida mais por meio de pactos do que por meio de regras imperativas -, tem-se, por outro lado, cada vez mais consciência da fragilidade e das consequências devastadoras do mau tratamento infantil. Quando falta responsabilidade sobre as crianças ou liberdade para os adultos, os efeitos são indeléveis. Seja para o florescimento ou para o fenecimento individual, não se apaga a influência que teve a família na formação da pessoa humana. Assim, todos os esforços ainda serão poucos para proteger as crianças do desamparo, e os adultos, da solidão.

\section{Referências}

BALLARANI, Gianni. Diritti dei figli e della famiglia. Antinomia o integrazione? In: TORRE, G. Dalla (Org.). Studi in onore di Giovanni Giacobbe: teoria generale, persone e famiglia. Milano: Giuffrè, 2010. t. 1, p. 473-489.

BARBOZA, Heloisa Helena. Novas tendências do direito de família. Revista da Faculdade de Direito da Universidade do Rio de Janeiro, Rio de Janeiro, v. 2, p. 227-245, 1994.

BARBOZA, Heloisa Helena. Reflexões sobre autonomia negocial. In: TEPEDINO, G.; FACHIN, L. E. (Coord.). O direito \& o tempo: embates jurídicos e utopias contemporâneas. Rio de Janeiro: Renovar, 2008. p. 407-423. Estudos em homenagem ao Professor Ricardo Lira.

BARROSO, Luís Roberto. O direito constitucional e a efetividade de suas normas: limites e possibilidades da Constituição brasileira. Rio de Janeiro: Renovar, 1990.

BAUMAN, Zygmunt. Sociedade do consumo e do crédito não funciona mais. Entrevista concedida ao jornalista Silio Boccanera 
do Programa Milênio, da Globo News. Disponível em: <http://www. conjur.com.br/2012-jan-27/ideias-milenio-zygmunt-bauman-sociologopolones>. Acesso em: 5 set. 2012.

BODIN DE MORAES, Maria Celina. A união entre pessoas do mesmo sexo: uma análise civil-constitucional. Revista Trimestral de Direito Civil, Rio de Janeiro, n. 1, p. 89-112, jan./mar. 2000.

BODINDE MORAES, Maria Celina. Deveres parentais e responsabilidade civil. Revista Brasileira de Direito de Família, n. 31, p. 39-66, 2005.

BODIN DE MORAES, Maria Celina. Na medida da pessoa humana. Rio de Janeiro: Renovar, 2010.

BOIN AGUIAR, Carla. Mediação e justiça restaurativa. São Paulo: Quartier Latin, 2009.

BOTTON, Alain de. Alógica de ser pai e mãe em tempos modernos. BBC Brasil Notícias, Disponível em: <http://www.bbc.co.uk/portuguese/ noticias/2011/08/110809_crianca_allan_boton_mdb.shtml>. Acesso em: 30 maio 2013.

CHABOT, Alexis. Sartre et le père: Le scénario Freud, les mots, l'idiot de la famille. Paris: Honoré Champion, 2012.

CHINELATO, Silmara Juny. Comentários ao Código Civil. v. 18. São Paulo: Saraiva, 2003. v. 18.

COOPER, David. A morte da família. São Paulo: Martins Fontes, 1986.

COSTA, Jurandir Freire. O ponto de vista do outro. Entrevistadora: Isabella Fraga. Ciência Hoje, v. 8, p. 6-7, mar. 2012. Suplemento.

CUNHA PEREIRA, Rodrigo da. Quem tem medo do casamento gay? [2011]. Disponível em: <http://www.ibdfam.org.br/artigos/detalhe/731>. Acesso em: 14 maio 2013.

DIAS, Maria Berenice. Manual de direito das famílias. 8. ed. rev. atual. e ampl. São Paulo: Revista dos Tribunais, 2011.

DOLTO, Françoise. Solidão. São Paulo: Martins Fontes, 1998. 
EEKELAAR, John. The end of an era. In: KATZ, S. N.; EEKELAAR, J.; MACLEAN, M. Cross currents: family law and policy in the United States and England. London: Oxford University Press, 2001. p. 106-120.

FACHIN, Luiz Edson. As intermitências da vida: o nascimento dos não filhos à luz do Código Civil Brasileiro. Rio de Janeiro: Forense, 2007.

FREEMAN, Michael D. A. The best interests of the child? Is the best interests of the child in the best interests of children? International Journal of Law, Policy and the Family, Oxford, v. 11, p. 360-388, 1997.

GAMA, Guilherme Calmon Nogueira da. Princípios constitucionais de direito de família: guarda compartilhada à luz da Lei n. 11.698/08: família, criança, adolescente e idoso. São Paulo: Atlas, 2008.

GARCIA, Roseana Moraes. A ética do cuidado e a sociedade democrática. Winnicott E-prints, v. 6, n.1, p. 79-87, 2011 Disponível em: <http://pepsic.bvsalud. org/scielo.php?script=sci_arttext\&pid=S167 9432X2011000100006\&lng=pt\&nrm=iso>. Acesso em: 2 maio 2013.

GIDDENS. Anthony. A transformação da intimidade: sexualidade, amor e erotismo nas sociedades modernas. São Paulo: Unesp, 1993.

GILLIGAN, James. Preventing violence: prospects for tomorrow. London: Thames \& Hudson, 2001.

GOLDSTEIN, Joseph et al. The best interests of the child: the least detrimental alternative. New York: Free Press, 1998.

GUERRA, Viviane N. de Azevedo. Violência de pais contra filhos: a tragédia revisitada. 3. ed. São Paulo: Cortez, 1998.

JOSEPH, Peter. Zeitgeist: moving forward. Official Online (YouTube) Release. Disponível em: <http://www.youtube.com/ watch?v=4Z9WVZddH9w>. Acesso em: 15 maio 2013.

LOBO NETO, Paulo Luiz. Direito ao estado de filiação e direito à origem genética: uma distinção necessária. Revista CEJ, Brasília, DF, n. 27, p. 47-56, out./dez. 2004.

LOBO NETO, Paulo Luiz. Paternidade socioafetiva e o retrocesso da Súmula $n^{\circ} 301$ do STJ. In: CONGRESSO BRASILEIRO DE DIREITO 
DE FAMÍLIA, 5., 2006, Belo Horizonte. Anais... Belo Horizonte: IBDFam, 2006. p. $795-810$.

MACHADO, Diego Carvalho. Capacidade de agir e pessoa humana: situações subjetivas existenciais sob a ótica civil-constitucional. Curitiba: Juruá, 2013.

MORO, Alfredo C. I diritti del minore e la nozione di interesse. In: Ambrosini, M. T. (Ed.). Scritti sul minore in memoria di Francesca Laura Morvillo. Milano: Giuffrè, 2001. p. 295-305.

NÁPOLI, Lucas. Dá pra ser feliz? Freud e Winnicott respondem: final. Disponível em: <http://lucasnapoli.com/2011/09/20/da-pra-ser-felizfreud-e-winnicott-respondem-final/>. Acesso em: 20 maio 2013.

NEUFELD, George; MATÉ, Gabor. Hold On to Your Kids. Why parents must matter more than peers. Toronto: Vintage Canada, 2005.

PARKINSON, Patrick. Family law and the indissolubility of parenthood. Cambridge: Cambridge University Press, 2011.

PITTMAN, Frank. Man enough: fathers, sons and the search for masculinity. New York: G. P. Putnam's Sons, 1993.

ROCA TRÍAS, Encarna. Familia y constitución. AFDUAM, n. 10, p. 207-224, 2007. Disponível em: <http://www.uam.es/otros/afduam/ pdf/10/207_228\%20ROCA.pdf>. Acesso em: 21 mar. 2013.

ROSEMBERG, Fúlvia; MARIANO, Carmem L.S. A convenção internacional sobre os direitos da criança: debates e tensões. Cadernos de Pesquisa, v. 40, n.141, p. 693-728, set./dez. 2010.

ROUDINESCO, Elisabeth. A família em desordem. Rio de Janeiro: Zahar, 2003.

SARLET, Ingo W. A eficácia dos direitos fundamentais. 9. ed. Porto Alegre: Livraria do Advogado, 2007.

SILVA PEREIRA, Tânia; MELO, Carolina Campos. Infância e juventude: os direitos fundamentais e os princípios constitucionais consolidados 
na Constituição de 1988. Revista Trimestral de Direito Civil, Rio de Janeiro, n. 3, p. 89-109, jul./set. 2000.

SINGLY, François de. La réinvention de la famille. Label France, Paris, n. 39, p. 16-17, abr. 2000.

STANZIONE, Pasquale. I rapporti genitori-figli nell'interpretazione della Corte Costituzionale. Sociologia del Diritto, Milano, n. 1, p. 13-25, 2007.

STANZIONE, Pasquale. Personalità, capacità e situazioni giuridiche del minore. Revista Trimestral de Direito Civil, Rio de Janeiro, n. 1, p. 113-122, jan./mar. 2000.

TABET, Gabriela. A inconstitucionalidade da presunção pater is est. Revista Trimestral de Direito Civil, Rio de Janeiro, n. 22, p. 71-95, abr./jun. 2005.

THALER, Richard H.; SUNSTEIN, Cass R. Nudge: improving decisions about health wealth and happiness. London: Penguin Books, 2008. (Kindle Edition).

THALER, RichardH; SUNSTEIN, CassR. Privatizingmarriage. The Monist, v. 91 , n. 3/4, p. 377-387, July/Oct. 2008. Disponível em: <http://secure. pdcnet.org/monist/content/monist_2008_0091_0003_0377_0387>. Acesso em: 21 mar. 2013.

THURLER, Ana Liési. Em nome da mãe: o não-reconhecimento paterno no Brasil. Florianópolis: Mulheres, 2009.

THURLER, Ana Liési. Paternidades como práticas políticas. Revista Jurídica da Presidência da República, Brasília, DF, v. 14, n. 102, p. 117-137, fev./maio 2012.

VELHO, Gilberto. Família e parentesco no Brasil contemporâneo: individualismo e projetos no universo das camadas médias. Interseções: Revista de Estudos Interdisciplinares, Rio de Janeiro, ano 3, n. 2, p. 45-52, jul./dez. 2001.

WAISELFISZ, Julio J. Mapa da violência 2012: atualização: homicídio de mulheres no Brasil. CEBELA/FLACSO, 2012. Disponível em: <http:// 
mapadaviolencia.org.br/pdf2012/MapaViolencia2012_atual_mulheres. pdf>. Acesso em: 20 maio 2013.

WINNICOTT, Donald W. Tudo começa em casa. São Paulo: Martins Fontes, 1999.

Recebido em: 10/06/13

Aprovado em: 12/07/13 